\title{
Effect of nitrocarburizing on corrosion resistance of carbon steel
}

\author{
Hani Aziz Ameen ${ }^{1}$ and Khairia Salman Hassan ${ }^{2}$ \\ ${ }^{1}$ Pumps Eng. Department -Technical College / Al-Musaib- Iraq - \\ E-mail:haniazizameen@yahoo.com \\ ${ }^{2}$ Institute of Technology - Baghdad / Mechanical Dept.-Iraq- \\ E-mail:almaden20002000@yahoo.com
}

\begin{abstract}
The effect of nitro carburizing on corrosion resistance of carbon steel (AISI / 1020) is investigated. Test specimen $20 \times 10 \mathrm{~mm}$ were manufactured according to ASTM. An one hour liquid nitriding at $550{ }^{\circ} \mathrm{C}$ followed by liquid carburizing at $925^{\circ} \mathrm{C}$ for one hour, at saline medium is done. The sight and microscopic hardness for the hardened layer after carburizing, nitration and nitrocarburizing are studied, as well a corrosion test by an electrochemical cell in sea water is done, where the test specimen represents the cell's positive pole. Tafel's equation was adopted to calculate the corrosion average. The microstructures of all specimen group (nitration, carburizing and nitrocarburizing) were photographed. The resulting phases after each heat treatment were tested by $\mathrm{x}$-ray diffraction apparatus. The results shown that the hardness of specimens increasing directly after the nitration, carburizing and nitrocarburizing processes. The corrosion average of the specimen after surface heat treatment was found to be less than that of the original metal.
\end{abstract}

Keywords: carbon steel, nitrocarburizing, corrosion

\section{INTRODUCTION}

Current global industry witnesses quick development in all fields. Engineering and mechanical industries are considered the essential foundation in fabrication and high- efficiency engineering designs to achieve the required goal of building highly dependable industry at reasonable cost. It is mandatory that machines components of steel are of specific mechanical properties [1], its surface shall be hard and wear - resistant with high resistance fatigue. Many researchers strived and many studies were conducted to improve the microstructure for purpose of increased hardening especially in the surface with preservation of core toughness to attain better properties for the metal. Surface hardening methods (nitriding, carburizing and nitrocarburizing) are selected, such methods are common to attain its requirements and efficiency. Nitrocarborizing is considered a heat treatment in which the steel's surface is saturated by one of the dispersion elements (carbon, nitrogen) in the atomic state which is obtained through analysis of some compounds and their contact with the steel's surface to form chemical bonds by absorption. Its infiltration inside steel is by dispersion.

Nitrocarburizing processes are conducted on steel components, e.g. valves, connecting rod of piston, crank shaft and cams in car engines, cutting tools and dies forming.

The metallurgical basics of nitrocarborizing are applied to control the process and determination of the formed layer (white dispersion layer) by nitrogen dispersion in steel. The phases obtained by nitrogen dispersion in the steel surface is iron nitride $\mathrm{Fe}_{4} \mathrm{~N}$ in $\mathrm{Y}$ iron up to $6 \%$ as well as $\mathrm{Fe}_{3} \mathrm{~N}$ phase in $\varepsilon$ iron up to $11 \%$ where these phases form the white surface layer. They are called white because it they preserve their colors after solution treatment by Nital [2] (Fig.$1-)$. 
Am. J. Sci. Ind. Res., 2010, 1(2): 320-325

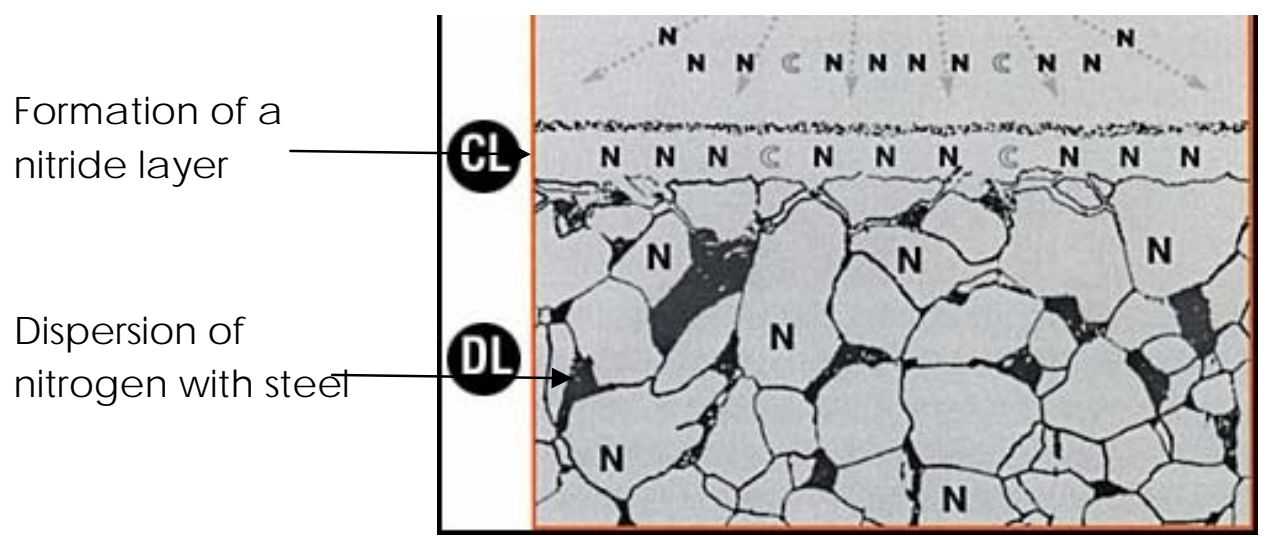

Fig.1 Dispersion of nitrogen in steel

This layer consists of non - metallic phases called nitrides [3], the proportion of such nitrides depends on the chemical composition of steel, in high carbon steel, $\varepsilon$ phase forms, in low carbon steel, $Y$ phase form. Detection process of the phases requires sophisticated technology, e.g. x-ray. The formed surface layer is featured by its hardness and existence of alloying elements which unite with nitrogen or carbon to form nitrides or carbides. Hardness of low carbon steel is (300-400) Hv and for high carbon steel is (700-1000) Hv. Nitrocarburizing is performed at $(530-600)^{\circ} \mathrm{C}$ and the depth of the formed layer ranges between $(0.2-1) \mathrm{mm}$ depending on the chemical composition of the base metal and treatment time. Franjo et al, [4] studied the improvement of properties of steels applying salt bath nitrocarburizing with post-oxidation. In the present study the effect of nitocarburizing on corrosion resistance of carbon steel AISI 1020 is investigated.

\section{The Practical aspect}

It secures the following :

1- Metal Selection:

Low - carbon 1020 according to AISI is chosen. Its chemical analysis is indicated in Table -1- . The chemical analysis was conducted by ARL Spectrometer .

Table -1- for Chemical Analysis of the used metal 1020

\begin{tabular}{|l|l|l|l|l|l|l|l|l|l|l|}
\hline Item & $\mathrm{C} \%$ & $\mathrm{Mn} \%$ & $\mathrm{P} \%$ & $\mathrm{~S} \%$ & $\mathrm{Si} \%$ & $\mathrm{Ni} \%$ & $\mathrm{Cr} \%$ & $\mathrm{Mo} \%$ & $\mathrm{Cu} \%$ & V\% \\
\hline Actual value & 0.169 & 0.65 & - & 0.014 & 0.019 & 0.004 & 0.024 & 0.054 & 0.022 & 0.002 \\
\hline $\begin{array}{l}\text { Standard } \\
\text { Value }\end{array}$ & $0.14-$ & $0.4-$ & - & - & - & - & 0.05 & - & - & - \\
\hline
\end{tabular}

2- Fabrication of specimen

Test specimen for adhesive wear property were fabricated as $10 \times 20 \mathrm{~mm}$ cylinders according to ASTM
3- Categorization of specimens

After completing fabrication, the specimen were categorized to groups as shown in Table-2-

Table -2- Categorization of test specimens

\begin{tabular}{|l|c|}
\hline Condition of specimen & Specimen's symbol \\
\hline Base metal without treatment & $\mathrm{A}$ \\
\hline Liquid nitriding & $\mathrm{B}$ \\
\hline Liquid Carburizing & $\mathrm{C}$ \\
\hline Liquid nitriding + liquid carburizing (nitrocarburizing) & $\mathrm{D}$ \\
\hline
\end{tabular}

4- Surface heat treatments 
1- Liquid (salt bath) nitriding

Liquid nitriding was performed on a group (B) of specimens shown in Table-2-. The nitriding process consisted of :

Preparation of a nitriding media of the under - shown salts and the weight proportions against them $(61 \%$ sodium cyanide , $24 \%$ sodium chloride and $15 \%$ potasim carbonates)

The above salts were placed in a stainless steel beaker and deposited in an oven at $550^{\circ} \mathrm{C}$ in order to melt the constituents before introducing the specimens. The above process was accompanied by heating the specimen in another oven at $150{ }^{\circ} \mathrm{C}$ to get rid of suspended moisture and avoiding the clamoring sounds caused by moisture in case of placing it inside the melter, and they were suspended in capillary steel wires, the beaker was taken out of the oven inside which the specimens were placed ( suspended in the melter), they were returned to the oven for one hour heating, then they were taken out of the oven and placed in water.

Salt bath (liquid) carburizing

Salt bath (liquid) carburizing was conducted on a group (C) of specimens shown in Table-2-. The specimens were flooded with hot saline solution at $925{ }^{\circ} \mathrm{C}$ for one hour, the saline solution used is sodium cyanide and potassium cyanide, this process was conducted in the gaseous phase. Reaction occurs first at the surface between the saline solution and atmospheric oxygen, the second reaction, however, occurring between the saline solution and steel. Sodium cyanide in different percentages according to the depth of the carburizing layer is used.

\section{Nitrocarburizing}

It was conducted on a group of specimen (D) shown in Table-2- . It considered of liquid nitriding process similar to that used on specimen group (B) of the same table. This was followed by liquid carburizing similar to the liquid carburizing conducted on specimen group (D).

\section{Tests and Examinations \\ $X$ - ray diffraction test}

$X$ - ray diffraction test is investigated, this was conducted on B,C and D specimens groups of Table2- Test results are shown in Table-3-for purpose of attaining the phases that were attained after the surface heat treatments.

Table -3- Results of X-Ray test

\begin{tabular}{|c|c|}
\hline Specimen symbol & Phase \\
\hline $\mathrm{B}$ & $\mathrm{FeN}+\mathrm{Fe}_{3} \mathrm{~N}+\mathrm{Fe}_{4} \mathrm{~N}$ \\
\hline $\mathrm{C}$ & $\mathrm{Fe}+\mathrm{FeC}+\mathrm{Fe}_{3} \mathrm{C}$ \\
\hline $\mathrm{D}$ & $\mathrm{Fe}_{2} \mathrm{~N}+\mathrm{Fe}_{3} \mathrm{C}+\mathrm{Fe}_{2} \mathrm{C}$ \\
\hline
\end{tabular}

\section{Test of Microstructure}

Test of microstructure on specimens groups in Table2- , the specimens were prepared as follows:

1- The specimens are treated with sandpaper Nos. 220, 320, 600, 800, 1000.

2- They are glossed with gloss cloth with auxiliary glossing of Alumina $\mathrm{Al}_{2} \mathrm{O}_{3}$.

3- Developing solution for the structure by use of Nital (2\% nitric acid $\mathrm{HNO}_{3}$ with $98 \%$ methyl alcohol)

4- Photographing the microstructure by a programmed microscope type (Advanced Polarizing Dark - field, Metallurgical Microscope MTj Corporation)

The photographs of the microstructure of specimens $A, B, C$ and $D$ are shown in Fig.(2)

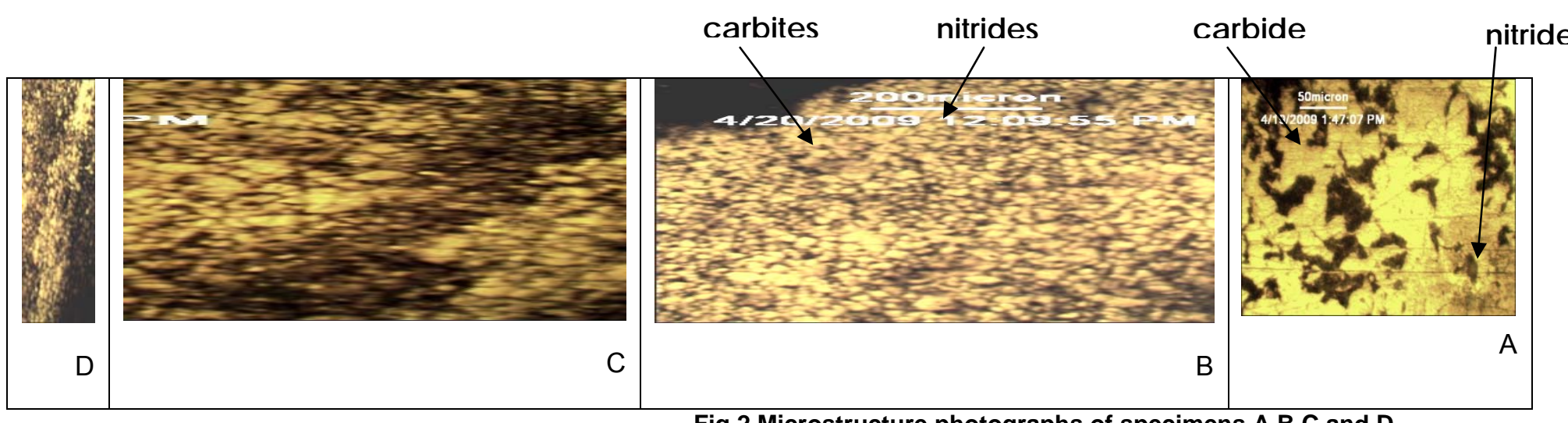

Fig.2 Microstructure photographs of specimens $A, B, C$ and $D$ 
Hardness Test: Hardness test was conducted on specimens groups in Table-2- by Hardness Tester, type Recwellc, Frank 147 /N Cm by a diamond cone with head angle $120^{\circ}$ and $150 \mathrm{Kg}$ load. Three reading were taken and the average was adopted. The test results are shown in Table-4-

Table-4- Hardness Test

\begin{tabular}{|c|c|}
\hline Group symbol & HRc \\
\hline A & 18 \\
\hline B & 51 \\
\hline C & 54 \\
\hline D & 56 \\
\hline
\end{tabular}

Microhardness:Microhradness was measured for specimens groups B,C and D in Table-2- by applying a $100 \mathrm{gm}$ load for 20 seconds and $0.1 \mathrm{~mm}$ lateral movements of the load by use of Hardness Tester, type micrometer USA. The hardness was calculated from the following law :

$$
H_{v}=1.854 \frac{P}{d_{a v}{ }^{2}}
$$

Where

$\mathrm{H}_{\mathrm{v}}=$ Vickers Hardness $\left(\mathrm{Kg} / \mathrm{mm}^{2}\right)$

$\mathrm{d}_{\mathrm{av}}=$ average trace diameter $(\mathrm{mm})$

$\mathrm{P}=$ applied force

The results are shown in Fig.(3)

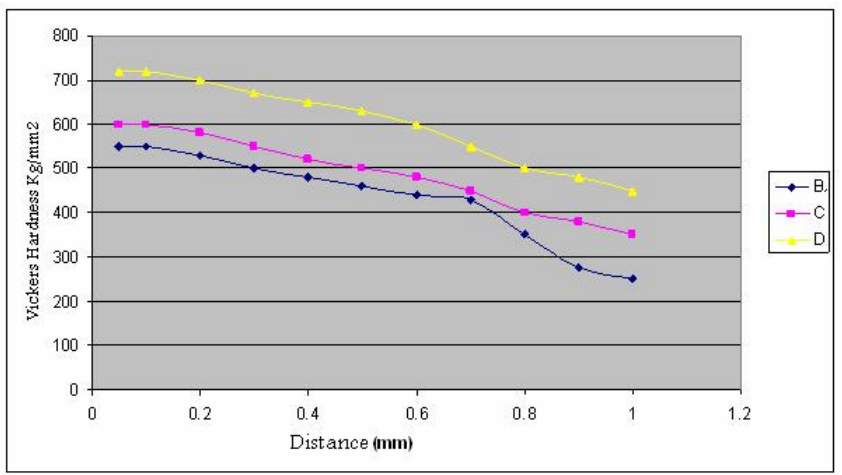

Fig.3 Results of microhardness test

\section{Corrosion Test}

1- Preparation of the water solution

The water medium in which flooding shall be done was prepared. It consists of seawater of
35 grams and sodium chloride with 1000 grams of distilled water. $\mathrm{pH}$ is measured by a pH meter and was found to be 6.9 .

\section{2- Electrochemical corrosion}

Electrochemical corrosion is done by Tafel's method. It consists of passing an electric current in an electrochemical cell (Fig.(4)) consisting of :

a- Positive pole representing the would be- tested specimen.

b- Negative pole representing the pole in which the electrons released from the anode pole converge, platinum element was used a pole in this cell.

c- Electrolyte of seawater.

d- Electric current source.

An electric current is passed at a specific potential according to metal type. Upon passage the current, the potential difference will change, thus indicating that this current causes corrosion. It is measured, that represents corrosion current which depends on Tafel Method for measuring corrosion average by taking contactors for the behavior of the anodic and cathodic metals. The intersection point represent the corrosion current, the results are shown in the following figures.

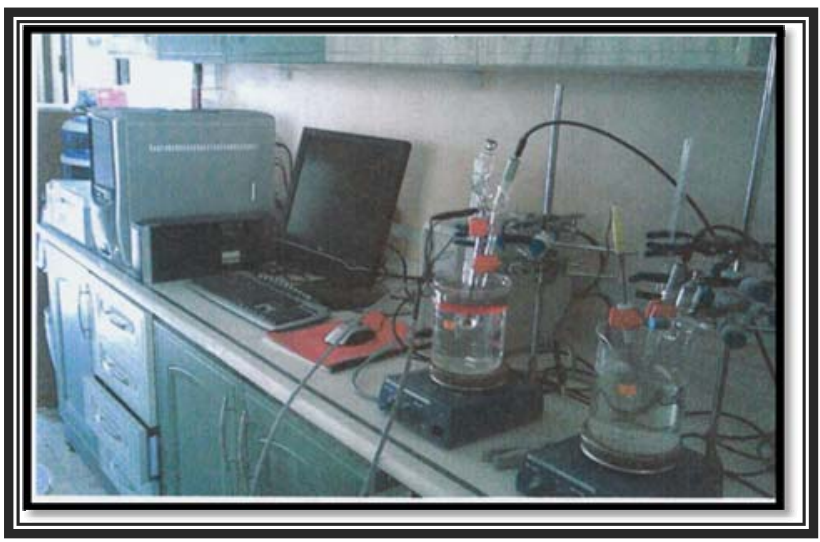

Fig.4 The electrochemical cell

The photos of corrosion are shown in Fig.(5) and Table-5- explain the results of electrochemical corrosion test after surface heat treatment. Fig.(6) explain the relationship between current density and the potential voltage for the group specimens $A, B, C$ and $D$ respectively. 
Am. J. Sci. Ind. Res., 2010, 1(2): 320-325

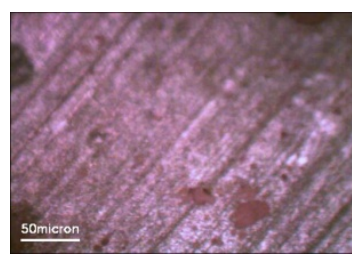

D

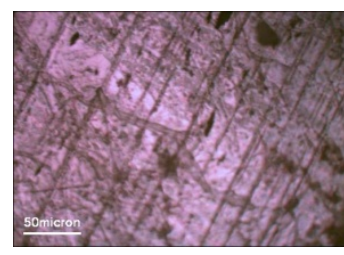

C

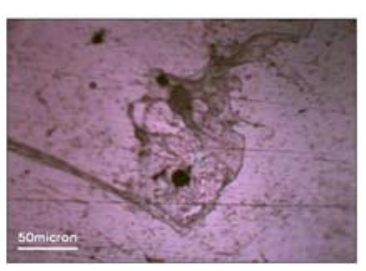

B

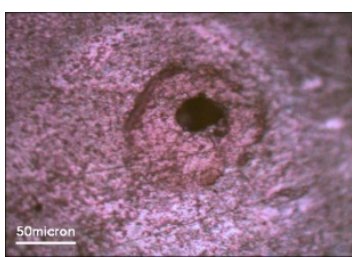

A

Fig.5 showing corrosion photos

Table -5- Results of electrochemical corrosion test after surface heat treatments

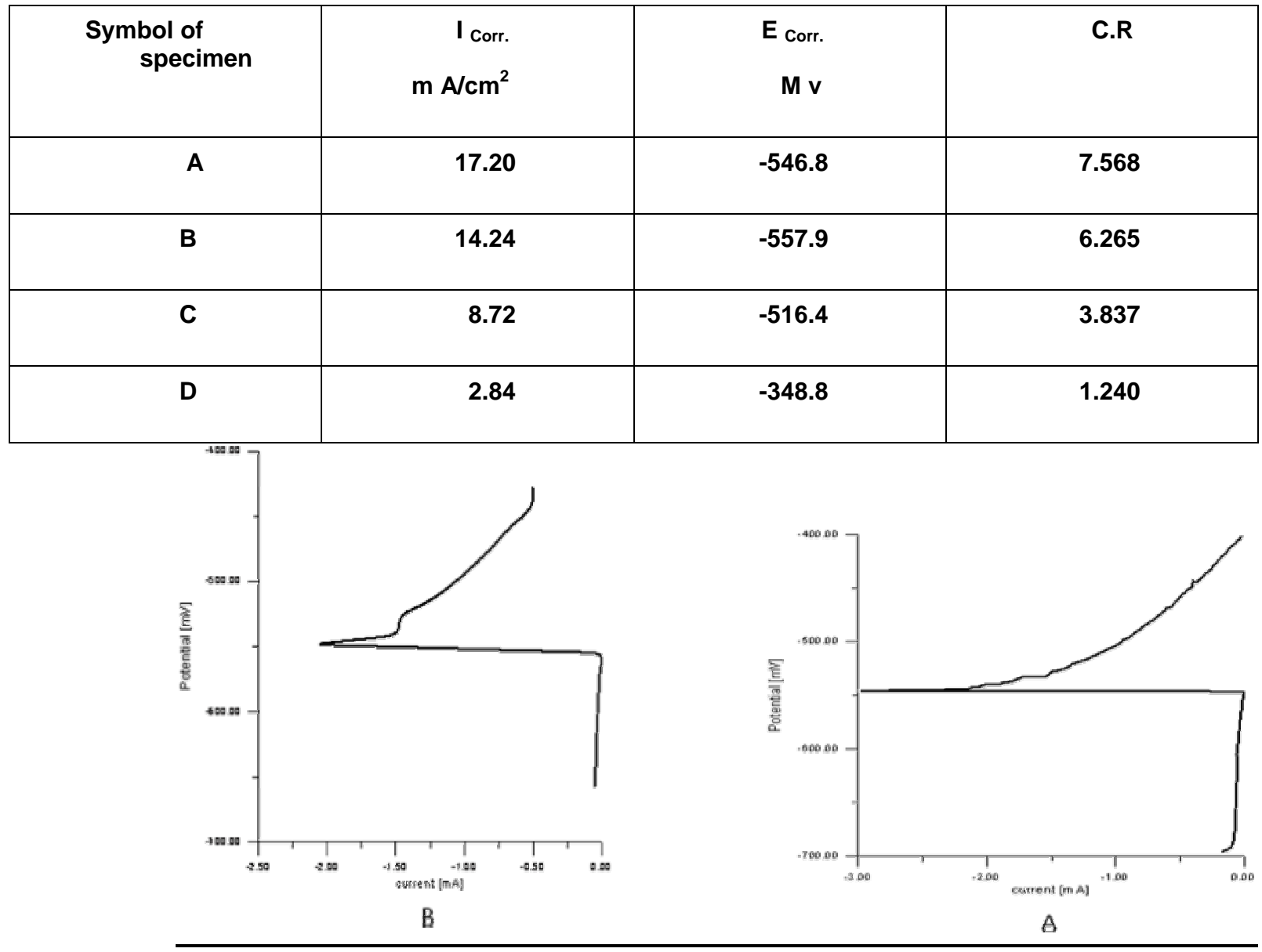


Am. J. Sci. Ind. Res., 2010, 1(2): 320-325
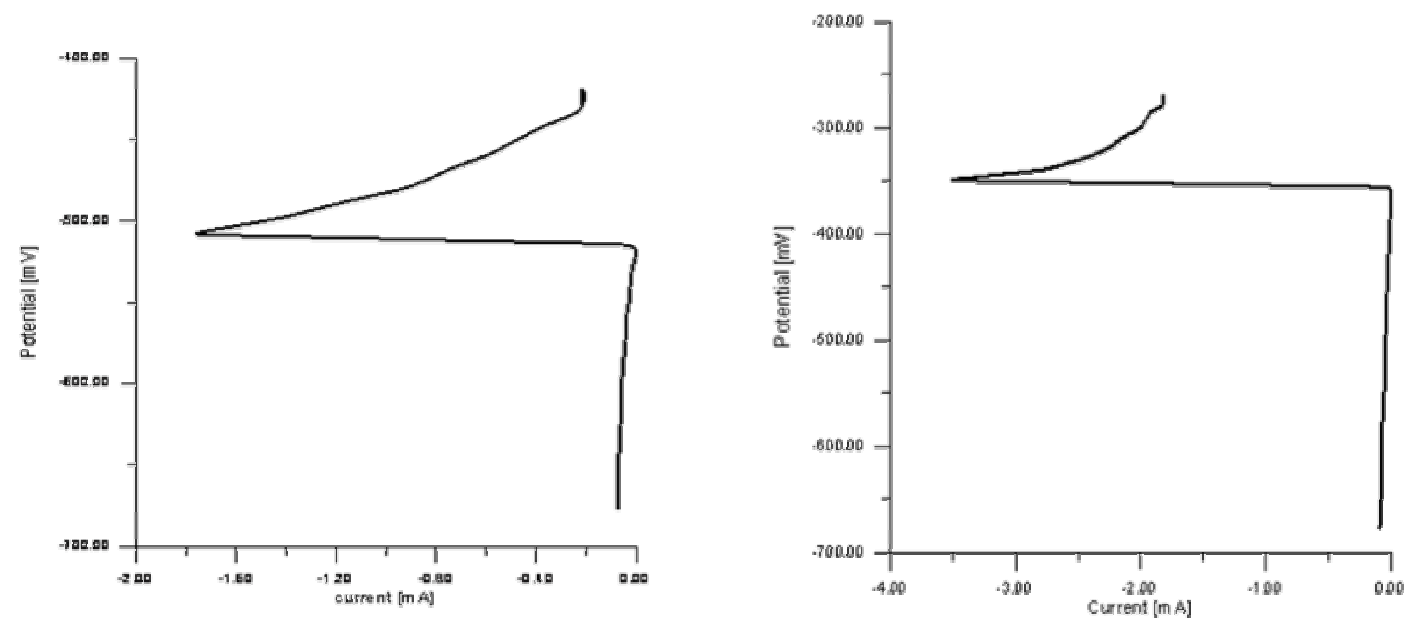

c

$\mathrm{R}$

Fig. 6 The relationship between current density and the potential of the electrochemical cell

\section{DISCUSSION OF RESULTS}

It was evidenced through microscopic test that the microstructure of low carbon steel, as represented by specimens of group $A$, consists of ferrite and perlite phases granules. The microscopic test and $\mathrm{x}$ ray test of group $B$ specimens ( by liquid nitriding) showed it iron nitrides $\mathrm{Fe}_{3} \mathrm{~N}$ for a specific depth, where the core was ferrite and perlite, test of liquid carburizing specimens, as represented by specimens of group $\mathrm{C}$, it showed the carbide network of cementite which vanish when going deep inside the specimen, this is shown that the surface layer was saturated for a specific depth with carbon, the core, however consists of ferrite and perlite phases similar to specimens of group A ( basic metal).

The microstructures of group $D$ specimens consisted of iron carbides and iron nitride, this was evidenced by results of $x$-ray diffraction and photos of the microstructure.

\section{CONCLUSIONS:}

Results of microhardness indicated directly proportional of values of hardnesses for $B, C$, and D groups specimens, after conducting nitriding, carburizing and nitrocarburizing respectively in comparison with A group specimens which had 180 $\mathrm{Hv}$ hardness. Hardness of nitride B specimen was up to $500 \mathrm{Hv}$, with $0.5 \mathrm{~mm}$ deep hardened layer. Hardness of carburize C specimen was up to 600 $\mathrm{Hv}$, with $0.85 \mathrm{~mm}$ deep hardened layer. The D group specimens after nitrocarburizing had its hardness up to $800 \mathrm{Hv}$ due to existence of carbide network $\mathrm{Fe}_{3} \mathrm{C}$ in the base of steel with nitride network, the depth of the hardened layer was $2 \mathrm{~mm}$. The corrosion average of the specimen after surface heat treatment was found to be less than that of the original metal.

\section{REFERENCES}

[1]" Metallagraphic preparation of rided and nitrocarburised components" www.Struers.com , 10/10/2006 .

[2] "The effect on nitriding on fatigue strength of structural alloys", V.F. Terntev M. S. Michugina, ISSN 1392 - 1207 Mechanika, 2007.

[3] Technical report 1/1999, "properties of nitrideed components, A result of the material and nitriding process", Rainer Leppanen.

[4] Franjo Cajner , Darko Landek and Ewa Stupnisek Lisac "Improvement of properties of steels applying salt bath nitrocarburizing with postoxidation" ISSN 1580-2949, MTAEC9, 37 (6), 333, 2003. 